\title{
IMPLEMENTATION OF TIME CONTROL STRATEGY ANALYSIS AT DISTRICT OFFICE DEVELOPMENT PROJECT IN EAST KUTAI REGENCY, INDONESIA
}

\author{
Nurfahrial Indra, Researcher \\ Kustamar, Lecturer \\ National Institute of Technology, Malang, East Java, Indonesia \\ *E-mail: indra.1234567@yahoo.com \\ ORCID: 0000-0002-6857-7194
}

\begin{abstract}
The purposes of this research are to 1) analysis the factors affecting time delay on project; 2) analyze the most dominant factor affecting time delay on project; 3) determine the strategies that should be done by the contractor to prevent time delay. The present research uses survey method by gathering opinions, experience, and attitude of respondents regarding to problems in the projects of Kaliorang District Office Development in East Kutai Regency, by taking primary data through questionnaire and secondary data from related institutions. Based on t test, partially factors significantly affecting time delay on the project of Kaliorang District Office Development in East Kutai Regency are Workers (X3) and Work Environment Factors (X7). The most dominant factor affecting time delay on the project is Workers Factor with $\beta$ coefficient value of $-0,787$. The strategies used to prevent the time delay on workers (X3) and work environment factors (X7) are: 1) The contractor should add workers who have skills as it needs and the experts who have their own qualifications; 2) Anticipating the environment condition of a site and making socialization to community and local government to determine land, layout or site that will be used.
\end{abstract}

\section{KEY WORDS}

Strategies, project, development, public service.

One of the construction project goals is the punctuality of project accomplishment. Based on data obtained from Public Works Office of East Kutai Regency, building project implementation in budget year 2016 consists of 8 (eight) works which are delayed about \pm 15 $-18 \%$ (data source, 2016) from the specified time, which lead to contract/addendum change effect in form of extra time.

For district office development recently, it has 18 project units of district office development spred to some Districts in East Kutai Regency. The delay causes loss both from the owner and the contractor, because the effect of tardiness is conflict and debate about what factors which cause it and the increase demands of cost and time.

Therefore, the prevention strategy of Kaliorang District Office Project in East Kutai Regency which is in the delay is not implemented well and further discussion is not conducted yet. Thus, this research is done.

Research Questions. In line with the explanation aforementioned, then the questions formulated to be the research material are as follows:

- What factors which affect time delay on Kaliorang District Office Development project in East Kutai Regency?

- Which is the most dominant factor that affects time delay on Kaliorang District Office Development project in East Kutai Regency?

- What strategy should be done to prevent time delay?

Research Objectives. Considering the Importance of Questions that have been formulated, then the objectives of this present research are:

- To analyse the factors affecting time delay on Kaliorang District Office Development project in East Kutai Regency?

- To analyse the most dominant factor affecting time delay on Kaliorang District Office Development project in East Kutai Regency? 
- To determine strategy that should be done by contractor to prevent time delay.

\section{METHODS OF RESEARCH}

The present research is done in Kaliorang District Office Development in East Kutai Regency in budget year 2016 which is in time delay.

Population and Sample. The population of the present research are the people who understand the condition involving directly in the work of Kaliorang District Office Development in East Kutai Regency in budget year 2016 which is in time delay, namely of 36 people consisting of 6 Owners taken from 1 Budget User / Budget User Authority, 1 Techincal Executive Officer, and 4 Field Supervisors; and from 36 contractors taken from 1 Project Manager, 1 Site Manager, 5 Project Engineer Managers, 4 Project Production Managers, 5 Project Financial and Personality, and 6 Foremen. Besides, from 8 Supervisor Consultants, it is taken from 2 Site Engineers, 3 Quality Engineers and 3 Chief Inspectors. In this research, the samples are taken randomly using disproportionate stratified random sampling (Sugiyono, 2010) with the formulation according to Slovin in Umar (2007) which is as follows:

$$
\mathrm{n}=\frac{\mathrm{N}}{1+\mathrm{N}^{2}}
$$

Where: N - Sample Size; N - Population Size = 36; E - Looseness Percentage = 0,05.

Identification of Research Variable and Definition. Operational Definition of research variable is something in whatever form determined by the researcher to be learnt so that information about it is found and the conclusion is then made (Sugiyono, 2010). Based on objective, then the identification of research variable is to know the factors affecting time delay in Kaliorang District Office Development in East Kutai Regency which can be seen in table 1 as follows:

Table 1 - Definition of Research Variable to Know the Factors Affecting Time Delay

\begin{tabular}{|c|c|}
\hline Variables & Definition \\
\hline $\begin{array}{l}\text { Finance } \\
\text { (X1) }\end{array}$ & $\begin{array}{l}\text { Finance is the fund provided to accomplish development works starting from material procurement, wages } \\
\text { payment, operation equipment, and so on. The indicator category is payment delay by contractor for the } \\
\text { workers, payment delay by contractor to supplier, and payment delay by owner to contractor. }\end{array}$ \\
\hline $\begin{array}{l}\text { Equipment } \\
\text { (X2) }\end{array}$ & $\begin{array}{l}\text { Equipment is the construction tool used to help and make workers easy in conducting development like } \\
\text { transporting, lifting, loading, moving, digging, mixing, and so forth with easy, fast, economica, and safe } \\
\text { way and having different type and capacity based on its functions. The indicator category is equipment } \\
\text { delivery delay, lack of equipment, the limited number of equipment, equipment capacity, and easy- } \\
\text { damaged equipment. }\end{array}$ \\
\hline $\begin{array}{l}\text { Workers } \\
\text { (X3) }\end{array}$ & $\begin{array}{l}\text { Workers are the people involved directly in the building implementation with the ability to perform the } \\
\text { works based on their skills and the responsibility given to them. The indicator category is the lack of } \\
\text { workers and supervisors who are not capable. }\end{array}$ \\
\hline $\begin{array}{l}\text { Material } \\
\quad(X 4)\end{array}$ & $\begin{array}{l}\text { Material is something available with certain specification and used to accomplish building works, both } \\
\text { seen from the total, the form, and the size. The indicator category is the lack of material, the delay of } \\
\text { material delivery, the change of material, and the damage of material in the storage. }\end{array}$ \\
\hline $\begin{array}{l}\text { Implementation } \\
\text { Method } \\
\text { (X5) }\end{array}$ & $\begin{array}{l}\text { Implementation Method is the way that should be followed in building that must be done based on the } \\
\text { orders, so that it leads to the expected work. The indicator category is the work which is not in line with } \\
\text { the determined ways, the work which does not follow specification, and the work which is not done well } \\
\text { and right. }\end{array}$ \\
\hline $\begin{array}{l}\text { Design Change } \\
\text { (X6) }\end{array}$ & $\begin{array}{l}\text { Design Change is the shifting/changing/reviewing activity of the existing design in the project } \\
\text { implementation, the work which is not in line with the initial plan (in terms of unachieved construction } \\
\text { dimension) which leads to the initial work which has been made and causes to design review). The } \\
\text { inidicator category is the frequent design change done by owner, change process delay from the plan. }\end{array}$ \\
\hline $\begin{array}{l}\text { Work Environment } \\
\text { (X7) }\end{array}$ & $\begin{array}{l}\text { Work Environment is the condition and situation of site where the project is implemented and related to } \\
\text { cultural social/custom of local people, topography, weather, and the available land. The indicator category } \\
\text { is the frequent rain, land change, layout or site which has been determined. }\end{array}$ \\
\hline
\end{tabular}

Source: Processed by the researcher from some references.

The variables studied in this present research are: Independent Variables $(X)$ consist of: Finance (X1), Equipment (X2), Workers (X3), Material (X4), Implementation Method (X5), Design Change (X6), Work Environment (X7).

Dependent Variable $(Y)$ consists of: Time Delay $(Y)$. 
To obtain data through questionnaire, some questions are made related to the variables and the indicators respectively, as seen from the table 2 and table 3.

Table 2 - Variable and Indicator of the Research (X Variable)

\begin{tabular}{|c|c|c|}
\hline Variables & Indicators & Questions \\
\hline $\begin{array}{l}\text { Finance } \\
\quad(\mathrm{X} 1)\end{array}$ & $\begin{array}{l}\text { Payment delay by contractor } \\
\text { to the workers (X1.1) } \\
\text { Payment delay by contractor } \\
\text { to the supplier (X1.2) } \\
\text { Payment delay of owner to } \\
\text { the contractor(X1.3) }\end{array}$ & $\begin{array}{l}\text { Does payment delay from contractor to the workers when } \\
\text { implementing the work affect on project accomplishment } \\
\text { time delay? } \\
\text { Does payment delay from contractor to the supplier } \\
\text { frequently happen when implementing the work? } \\
\text { Is there any payment delay done by owner to contractor in } \\
\text { the project implementation? }\end{array}$ \\
\hline $\begin{array}{l}\text { Equipment } \\
\qquad(\mathrm{X} 2)\end{array}$ & $\begin{array}{l}\text { Equipment Delivery Delay } \\
\text { (X2.1) } \\
\text { Lack of Equipment (X2.2) } \\
\text { Equipment Capacity (X2.3) } \\
\text { Easy-damaged equipment } \\
\text { (X2.4) }\end{array}$ & $\begin{array}{l}\text { Does equipment delivery delay frequently happen when it is } \\
\text { in the project implementation? } \\
\text { What lack of equipment owned by contractor in } \\
\text { implementing the work? } \\
\text { What equipment capacity which is not in line to serve the } \\
\text { work volume needed? } \\
\text { Does the existing equipment have damage in implementing } \\
\text { the work? }\end{array}$ \\
\hline $\begin{array}{l}\text { Workers } \\
\text { (X3) }\end{array}$ & $\begin{array}{l}\text { Lack of Workers (X3.1) } \\
\text { Workers do not have good } \\
\text { working skill (X3.2) } \\
\text { Inadequate field supervisors } \\
\text { (X3.3) }\end{array}$ & $\begin{array}{l}\text { Does lack of workers happen when implementing the work? } \\
\text { Are there many workers who do not have good working skill } \\
\text { when implementing the work? } \\
\text { Does inadequate field supervisor direct and contro the work } \\
\text { implementation? (contractor) }\end{array}$ \\
\hline $\begin{array}{l}\text { Material } \\
\quad(X 4)\end{array}$ & $\begin{array}{l}\text { Lack of Material (X4.1) } \\
\text { The Frequent Dearth of } \\
\text { Material (X4.2) } \\
\text { Delay of Material Delivery } \\
\text { (X4.3) } \\
\text { Material damage in storage } \\
\text { (X.4.4) }\end{array}$ & $\begin{array}{l}\text { Does lack of material frequently happen in the project } \\
\text { implementation? } \\
\text { Does the dearth of material (non local) frequently occur } \\
\text { because it should be brought from out of the region? } \\
\text { Does the delay of material delivery frequently happen to the } \\
\text { project site? } \\
\text { Is there any material damage in the storage when } \\
\text { implementing the project? }\end{array}$ \\
\hline $\begin{array}{l}\text { Implementation } \\
\text { Method } \\
\text { (X5) }\end{array}$ & $\begin{array}{l}\text { The work is not in line with } \\
\text { the determined ways (X5.1) } \\
\text { The work does not follow } \\
\text { specification (X5.2) } \\
\text { The work is not implemented } \\
\text { with good and right method } \\
\text { (X5.3) }\end{array}$ & $\begin{array}{l}\text { Is the work implemented not in line with the determined } \\
\text { ways? } \\
\text { Does the implemented work not follow technical } \\
\text { specifications which have been determined? } \\
\text { Are all works not implemented with good and right method? }\end{array}$ \\
\hline $\begin{array}{l}\text { Design Change } \\
\text { (X6) }\end{array}$ & $\begin{array}{l}\text { The frequent Design Change } \\
\text { made by owner (X6.1) } \\
\text { Delay of change process } \\
\text { from plan }(\mathrm{X} 6.2)\end{array}$ & $\begin{array}{l}\text { Does design change frequently happen made by owner } \\
\text { because of the changed function from the initial plan when } \\
\text { implementing the work? } \\
\text { Does delay of change process from plan occur when } \\
\text { implanting the work? }\end{array}$ \\
\hline $\begin{array}{l}\text { Work } \\
\text { Environment } \\
\quad(X 7)\end{array}$ & $\begin{array}{l}\text { Frequent Rain (X7.1) } \\
\text { Available Land (X7.2) }\end{array}$ & $\begin{array}{l}\text { Does rain frequently happen when implementing the work so } \\
\text { that it obstructs the project? } \\
\text { Is there any change of land, layout, and site which have } \\
\text { been determined? }\end{array}$ \\
\hline
\end{tabular}

Table 3 - Variable and Indicator of the Research (Y Variable)

\begin{tabular}{|c|l|}
\hline Variable & \multicolumn{1}{c|}{ Question } \\
\hline Time Delay $(\mathrm{Y})$ & $\begin{array}{l}\text { Does Kaliorang District Office Development in East Kutai Regency experience time delay } \\
\text { from the determined schedule? }\end{array}$ \\
\hline
\end{tabular}

The scoring criteria of question answers in table 2 using likert which is as follows:

1 = Extremely Not Affecting;

2 = Not Affecting;

3 = Less Affecting;

4 = Affecting;

$5=$ Extremely Affecting. 
Data Collection Method. Data collection method in this research uses questionnaire method. The final objective of this research is to know the factors affecting time delay in the project of Kaliorang District Office Development in East Kutai Regency and the strategy which should be done to prevent it. The present research employs survey method by netting opinions, experience, and attitudes of respondents regarding to problems had in Kaliorang District Office Development Projects in East Kutai Regency, which is by taking primary data through questionnaire and secondary data from related institution (Palinkas, 2015). Based on the factors, it is continued by determining variables to be taken as questions which will be measured in form of questionnaire (Kawulich, 2005: Johnson et. al., 1982)

Primary data collection, or direct collection, is obtained by conducting interview and sharing the questionnaire sheets directly to the respondents related directly to Kaliorang District Office Development which is in time delay.

Secondary data, or indirect data, is the data or information obtained from literary study and the data which have been processed, including: the data used as the theory from research, which is obtained from books, theories, concepts, variables from notes, journals, articles, and so on in order to strengthen and support this study as well as from the related research previously. Moreover, the data are Tender Documents, Contract Documents, Project Figure, and Time Schedule which contain data of project implementation delay.

Validation Test. In this validity test, it later can show how far the speed level of measuring tool usage towards the indication which is willing to be measured. The questionnaire can be considered valid if the questions in the questionnaire or the questionnaire itself can revea something which will be measured by the questionnaire (Singarimbun \& Effendi, 2006). The validity of an instrument can be known by comparing correlation index of Product Moment Person with significance level of 0,05 (5\%) as the critical score, comparing $r_{\text {count }}$ and $r_{\text {table }}$ in appendix 3 , so that instrument validity can be determined by following criteria by (Onwuegbuzie, 2007): $r_{\text {count }}>r_{\text {table: }}$ Valid; $r_{\text {count }}<r_{\text {table: }}$ Invalid.

Reliability Test. Reliability Test is the index showing how far measuring tool can be trusted or can be relied. In other words, reliability shows consistency of a measuring tool in measuring same indications (Singarimbun \& Effendi, 2006). In this research, reliability test uses the approach of Alpha Cronbanch. Instrument is considered reliable if the value of Alpha Cronbanch > 0,6.

Data Processing and Data Analysis. Data obtained from survey result (questionnaire) are then processed to get information in form of tabe. The result of the data processing is used to answer research questions (Burns \& Bursn, 2000). Moreover, data analysis technique used is factor analysis and multiple linear analysis. Data of questionnaire result which is in the range 1 to 5 from each variables are then recounted, so that from each variables containing some indicators, it will result to one score only which is afterwards analyzed by using factor analysis and multiple linear analysis (Neter et. al., 1996). The data processing is done by the help of Statistical Package for Social Science (SPSS) for Windows.

Strategy Implementation to Prevent Delay. From the result of factor analysis and multiple linear regression analysis, strategy implementation towards variables assumed as the causes of delay can be determined so that it can be a reference or corrective action in district office development project which is not in delay.

The steps of strategy determination that should be done by contractor to prevent the factors in the present research are as follows:

- Seeing the multiple linear regression analysis towards independent variables which have significant value;

- Determining the most affecting independent variable (factor) toward time delay. The most dominant variable is the variable affecting significantly and has the biggest $\beta$ Coefficient value.

From the result above, strategy critera towards variables can be determined as viewed in table 4. Based on the strategy criteria aforementioned, strategy/corrective action of project time delay can be implemented both from owner, contractor, and supervisor consultant towards the variables as seen in table 5 . 
Table 4 - Strategy Criteria

\begin{tabular}{|c|l|}
\hline $\begin{array}{c}\text { Variables } \\
(\mathrm{X} 1)\end{array}$ & $\begin{array}{l}\text { Having adequate working capital and not depending on termination and being distributed to } \\
\text { the field as in line with the needs. }\end{array}$ \\
\hline $\begin{array}{c}\text { Equipment } \\
(\mathrm{X} 2)\end{array}$ & $\begin{array}{l}\text { The number and the capacity of equipment are in line with the need. It is completely } \\
\text { realized in the mobilization period. }\end{array}$ \\
\hline $\begin{array}{c}\text { Workers } \\
(\mathrm{X} 3)\end{array}$ & $\begin{array}{l}\text { Providing enough workers, workers who have skill, technical ability and administration } \\
\text { which is in accordance with the working needs. }\end{array}$ \\
\hline $\begin{array}{c}\text { Material } \\
(\mathrm{X} 4)\end{array}$ & $\begin{array}{l}\text { Having quarry with adequate deposit and recommended quality. Non-local material } \\
\text { procurement should be planned well. }\end{array}$ \\
\hline $\begin{array}{c}\text { Implementation } \\
\text { Method } \\
(\mathrm{X} 5)\end{array}$ & $\begin{array}{l}\text { The work is implemented based on contract documents and SOP and the orders of every } \\
\text { item are arranged in detail and can be implemented. }\end{array}$ \\
\hline $\begin{array}{c}\text { Design Change } \\
(\mathrm{X} 6)\end{array}$ & Preparing complete design, doing mutual check and accomplishing quickly. \\
\hline $\begin{array}{c}\text { Work Environment } \\
(\mathrm{X} 7)\end{array}$ & $\begin{array}{l}\text { Before the project is started, socialization should be done first to the community and local } \\
\text { government regarding to and determination, layout or site that is used. }\end{array}$ \\
\hline
\end{tabular}

Source: Processed by the researcher from some references.

Table 5 - Strategy/Corrective Action of Project Time Delay

\begin{tabular}{|c|c|}
\hline Variables & Strategy/Corrective Action \\
\hline $\begin{array}{l}\text { Finance } \\
\quad(\mathrm{X} 1)\end{array}$ & $\begin{array}{l}\text { The owner as the project owner is expected to provide administrative payment terms, } \\
\text { coordinate with the State finance office, so that payment is guaranteed to the contractor } \\
\text { smoothly, the Contractor must strive to fix the financial management of the company in } \\
\text { managing and using project finance properly, maintaining cash flow for the smooth running of } \\
\text { the work, can pay workers' wages regularly and on time. The consultant checks and ratifies } \\
\text { the terms payment certificate data made by the contractor according to the stipulated time }\end{array}$ \\
\hline $\begin{array}{l}\text { Equipment } \\
\qquad(\mathrm{X} 2)\end{array}$ & $\begin{array}{l}\text { The owner agrees the plan of providing equipment made by the contractor and has been } \\
\text { checked by the consultant who supervises and controls the equipment procurement, the } \\
\text { Contraktor must provide the equipments as in line with the nuber and the equipment type } \\
\text { offered in the contract with a ready-to-use condition. The Consutant checks and supervises } \\
\text { the executive contractor of equipment procurement and makes supervising report for the } \\
\text { owner. }\end{array}$ \\
\hline $\begin{array}{l}\text { Workers } \\
\text { (X3) }\end{array}$ & $\begin{array}{l}\text { Owner asks contractor to use skilled workers based on needs, Contractor must have } \\
\text { personnel who can manage the activities both technical and administrative so that quality, } \\
\text { volume, and time are in line with the plan, the Contractor must be able to supervise based on } \\
\text { duties and responsibilities, so that the project implemented can be in accordance with quality, } \\
\text { vilume, cost and in line with the planned time. }\end{array}$ \\
\hline $\begin{array}{l}\text { Material } \\
\quad(X 4)\end{array}$ & $\begin{array}{l}\text { The contractor has quarry with sufficient deposit and recommended quality. Procurement of } \\
\text { non-local materials must be planned properly. The use of materials in accordance with the } \\
\text { plan to avoid excess use of material (waste material); the Cnsultant must be able to supervise } \\
\text { in accordance with their duties and responsibilities, so that projects can be conducted with the } \\
\text { right quality, right volume, right costs in accordance with the planned time. }\end{array}$ \\
\hline $\begin{array}{l}\text { Implementation } \\
\text { Method } \\
\text { (X5) }\end{array}$ & $\begin{array}{l}\text { The owner needs to immediately arrane a workframe of reference (KAK) and technical } \\
\text { specifications in accordance with a more complete and detailed plan, so that the contractor } \\
\text { can perform the work following the workframe reference (KAK) of technical specifications that } \\
\text { have been determined in accordance with the plan. The consultant must be able to supervise } \\
\text { in accordance with their duties and responsibilities, so that the project can be implemented } \\
\text { with the right quality, right volume, right cost according to the planned time. }\end{array}$ \\
\hline $\begin{array}{l}\text { Design Change } \\
(\mathrm{X} 6)\end{array}$ & $\begin{array}{l}\text { In the initial measurement of implementation, the contractor and the consultant immediately } \\
\text { report the design that is not in accordance with the real conditions in the field, the contractor } \\
\text { calculates the quantity and Cost Budget Plan (RAB) due to design change to be submitted to } \\
\text { the owner. The owner immediately amends the contract due to changes in design with the } \\
\text { contractor. The owner makes the technical specifications of the planning more complete, so } \\
\text { that the results of planning when used in construction do not undergo significant changes. }\end{array}$ \\
\hline $\begin{array}{l}\text { Work } \\
\text { Environment } \\
\quad(X 7)\end{array}$ & $\begin{array}{l}\text { Before the project is started, socialization should be done by the owner, contractor, and } \\
\text { supervisor consultant together to the community and local government regarding to land } \\
\text { determination, layout or site that is used, makes work environment which has considered } \\
\text { condition of site and the weather which will happen when implementing the project. }\end{array}$ \\
\hline
\end{tabular}

Source: Processed by the researcher from some references. 


\section{RESULTS AND DISCUSSION}

Research Instrument Test. Item validity test respectively like variables of Finance, Equipment, Workers, Material, Implementation Method, Design Change, and Work Environment in this research is done with software SPSS 23 for Windows, as seen in table 7.

Table 6 - Population and Sample

\begin{tabular}{|c|c|c|c|}
\hline No & Description & Population & Sample \\
\hline \multirow[t]{4}{*}{1} & \begin{tabular}{|c|} 
Owner \\
\end{tabular} & & \\
\hline & Budget User/Budget Authority (PA/KPA) & 1 & 1 \\
\hline & Commitment Making Official (PPK) & 1 & 1 \\
\hline & Field Supervisor & 4 & 4 \\
\hline \multirow[t]{7}{*}{2} & Contractor & & \\
\hline & Project Manager & 1 & 1 \\
\hline & Site Manager & 1 & 1 \\
\hline & Project Engineer Manager & 5 & 4 \\
\hline & Project Productoin Manager & 4 & 3 \\
\hline & Project Financial \& Personality & 5 & 4 \\
\hline & Foreman & 6 & 6 \\
\hline \multirow[t]{5}{*}{3} & Supervisor Consultant & & \\
\hline & Site Engineer & 2 & 2 \\
\hline & Quality Engineer & 3 & 3 \\
\hline & Chief Inspector & 3 & 3 \\
\hline & Total & 36 & 33 \\
\hline
\end{tabular}

Source: Calculation Result.

Table 7 - Validity Test Result

\begin{tabular}{|c|c|c|c|c|c|}
\hline Factors & Indicators & Correlation Coefficient & Value of $r_{\text {table }}$ & $P$-Value & Result \\
\hline \multirow{3}{*}{ Finance $(\mathrm{XI})$} & $\mathrm{XI.1}$ & 0.760 & 0.355 & 0.000 & Valid \\
\hline & $\mathrm{XI} .2$ & 0.749 & 0.355 & 0.000 & Valid \\
\hline & $\mathrm{XI} .3$ & 0.841 & 0.355 & 0.000 & Valid \\
\hline \multirow{4}{*}{ Equipment (X2) } & $\mathrm{X} 2.1$ & 0.795 & 0.355 & 0.000 & Valid \\
\hline & $\mathrm{X} 2.2$ & 0.844 & 0.355 & 0.000 & Valid \\
\hline & $\mathrm{X} 2.3$ & 0.561 & 0.355 & 0.001 & Valid \\
\hline & $\mathrm{X} 2.4$ & 0.702 & 0.355 & 0.000 & Valid \\
\hline \multirow{3}{*}{ Workers (X3) } & $\mathrm{X} 3.1$ & 0.889 & 0.355 & 0.000 & Valid \\
\hline & $\mathrm{X} 3.2$ & 0.842 & 0.355 & 0.000 & Valid \\
\hline & $\mathrm{X} 3.3$ & 0.818 & 0.355 & 0.000 & Valid \\
\hline \multirow{4}{*}{ Material (X4) } & $\mathrm{X} 4.1$ & 0.868 & 0.355 & 0.002 & Valid \\
\hline & $\mathrm{X} 4.2$ & 0.593 & 0.355 & 0.000 & Valid \\
\hline & $\mathrm{X} 4.3$ & 0.691 & 0.355 & 0.000 & Valid \\
\hline & $\mathrm{X} 4.4$ & 0.659 & 0.355 & 0.000 & Valid \\
\hline \multirow{3}{*}{ Implementation Method (X5) } & $\mathrm{X} 5.1$ & 0.707 & 0.355 & 0.000 & Valid \\
\hline & $\mathrm{X} 5.2$ & 0.763 & 0.355 & 0.000 & Valid \\
\hline & $\mathrm{X} 5.3$ & 0.793 & 0.355 & 0.000 & Valid \\
\hline \multirow{2}{*}{ Design Change (X6) } & $X 6.1$ & 0.836 & 0.355 & 0.000 & Valid \\
\hline & $\mathrm{X} 6.2$ & 0.873 & 0.355 & 0.000 & Valid \\
\hline \multirow{2}{*}{ Work Environment (X7) } & $\mathrm{X7.1}$ & 0.929 & 0.355 & 0.000 & Valid \\
\hline & $\mathrm{X} 7.2$ & 0.909 & 0.355 & 0.000 & Valid \\
\hline
\end{tabular}

Source: Analysis of SPSS.23.

Reliability test is conducted by using the help of software SPSS 23 in which reliability test uses coefficient Alpha Cronbach to variables: finance (XI), equipment (X2), workers (X3), material (X4), implementation method (X5), change design (X6), and Work Environment (X7) like in the Table 8.

From Table 8 coefficient of Alpha Cronbach is obtained for variables of Finance (XI), Equipment (X2), Workers (X3), Material (X4), Implementation Method (X5), Design Change (X6), and Work Environment (X7) which are bigger than 0,6 . Thus, it can be concluded that the indicator used to measure the variables are relied and reliable. 
Table 8 - Reliability Test Result

\begin{tabular}{|c|c|c|}
\hline Variables & Cronbach's Alpha & Results \\
\hline Finance (XI) & 0.666 & Reliable \\
\hline Equipment (X2) & 0.703 & Reliable \\
\hline Workers (X3) & 0.808 & Reliable \\
\hline Material (X4) & 0.643 & Reliable \\
\hline Implementation Method (X5) & 0.618 & Reliable \\
\hline Design Change (X6) & 0.630 & Reliable \\
\hline Work Environment (X7) & 0.813 & Reliable \\
\hline
\end{tabular}

\section{RESULTS AND DISCUSSION}

From factor extraction result which is continued by doing interpretation towards loading factor of every items, it is known that Latent Variables like Finance (XI), Equipment (X2), Workers (X3), Material (X4), Implementation Method (X5), Design Change (X6) and Work Environment (X7) can be grouped into manifest variables which are explained as follows:

Finance Variable $(\mathrm{XI})$, is formed with manifest variable indicator consisting of: payment delay by contractor to the workers (X1.1), Payment delay by contractor to the supplier (X1.2), and Payment delay by owner to the contractor (X1.3).

Equipment Variable (X2), is formed with manifest variable indicator comprising of: equipment delivery (X2.1), Lack of Equipment (X2.2), Inadequate equipment capacity (X2.3), and the easy-damaged equipment (X2.4).

Workers Variable (X3), is formed with manifest variables consisting of: dearth of material (X3.1), frequent change on material in form and function (X3.3) and material damage in the storage (X3.4).

Material Variable (X4), is formed with manifest variables consisting of: dearth of material (X4.1), frequent change on material in form and function (X4.3) and material damage in the storage (X4.4).

Implementation method variable (X5), is formed with manifest variables consisting of: the work done is not in line with the determined ways (X5.1), the work does not follow the specifications (X5.2) and the work is not done in a good and right method (X5.3).

Design change variable (X6), is formed with manifest variables consisting of: frequent design change by owner (X6.1) and the initial plan designed by the owner is not fulfilled (X6.2).

Work environment variable (X7), ), is formed with manifest variables consisting of: Air temperature (X7.1) and the change of land, layout or site which has been determined (X7.2).

Regression analysis is used to obtain the factors affecting Time Delay and the most dominant factors affecting Time Delay in data processing by using multiple linear regression analysis; some steps are done to look for the relation between independent and dependent variables. Based on data processing result by using software SPSS.23 (see Appendix 7), the outline is explained as seen in Table 9 below:

Table 9 - Outline of Regression Analysis Result

\begin{tabular}{|c|c|c|c|c|}
\hline Variables & Coefficient $\beta$ & $t_{\text {count }}$ & $P$-value & Detail \\
\hline Constants & 5,317 & 1,984 & 0,058 & Not significant \\
\hline Finance Factor $(\mathrm{XI})$ & $-0,061$ & $-0,160$ & 0,874 & Not significant \\
\hline Equipment Factor (X2) & $-0,399$ & $-1,413$ & 0,170 & Not significant \\
\hline Workers Factor (X3) & $-0,787$ & $-2,995$ & 0,006 & Significant \\
\hline Material Factor (X4) & $-0,224$ & $-0,784$ & 0,440 & Not significant \\
\hline Implementation Method Factor (X5) & 0,323 & 1,331 & 0,195 & Not significant \\
\hline Design Change Factor $(\mathrm{X} 6)$ & 0,018 & 0,067 & 0,947 & Not significant \\
\hline Work Environment Factor (X7) & 0,603 & 2,595 & 0,016 & Significant \\
\hline $\begin{array}{l}N=0,05 \\
\mathrm{R}^{2}=0,376 \\
\mathrm{R}=0,613 \\
\text { F-count }=2,154 \\
\text { F-tabld }(0.05,7,25)=2,400 \\
p \text {-value }=0,075 \\
\text { t-tabld }(0.05,25)=1.708\end{array}$ & & & & \\
\hline
\end{tabular}

Source: Analysis of SPSS.23. 
Based on table 9, it is seen that not all independent variables have significant value. Independent variables which have significant value (affecting significantly towards Time Delay) are Workers Factor and Work Environment Factor. While, the variables which do not have significant value (affecting but not significantly towards Time Delay) are Finance, Equipment, Material, Implementation Method, and Design Change Factors.

Strategy Discussion to Prevent Problems Related to the Factors Affecting Significantly. Based on regression analysis result, it is obtained that Workers and Work Environment Factors are the factors affecting significantly in line. Then, the factors affecting significantly towards Time Delay can be explained that Workers Variable (X3), is formed with manifest variables consisting of Lack of workers (X3.1), Many unskilled workers (X3.2), and Inadequate supervisors (contractor party) (X3.3). Work Environment Variable, is formed with manifest variabes comprising of Air temperature (X7.1) and the Change of land, layout or site which has been determined (X7.2). Afterwards, the strategy used towards the factors affecting Time Delay significantly will be discussed.

Workers Factor is the variable having coefficient value of $\beta$ of 0,787 and value of $p$ value of 0,006 is less than $\alpha=0.05$. It means that in the present research, the factor affecting Time Delay significantly is Workers Factor. It means, Time Delay is really influenced by Workers Factor. The Coefficient Value of $\beta$ which is negative indicating that if the work done is not in line with the determined time so that delay occurs. Then, to know which indicator that mostly affects Time Delay in Workers Factor, it can be seen from the high communality value as seen on Table 10 as follows:

Table 10 - Communality Value in Workers Factor

\begin{tabular}{|c|c|c|}
\hline Manifest Variables & Description & Communality Value \\
\hline X3.1 & Dearth of Workers & 0,784 \\
\hline X3.2 & Many unskilled workers & 0,717 \\
\hline X3.3 & Inadequate supervisors (contractor party) & 0,668 \\
\hline
\end{tabular}

Source: Analysis Result of SPSS.23.

From table 10, it is known that the indicator of Workers Factor which is the most dominant affecting Time Delay is Dearth of Workers so that it obstructs the work of 0,784 . Then, the strategy used to prevent it can be seen in the Table 11 as follows:

Table 11 - Preventive Strategy of Time Delay Causing Factor in Workers Factor

\begin{tabular}{|c|c|c|}
\hline Factor & Problem & $\begin{array}{c}\text { Strategies } \\
\end{array}$ \\
\hline \multirow{3}{*}{ Workers } & Dearth of Workers & Contractor should supply workers needed in the project \\
\hline & Many unskilled workers & $\begin{array}{l}\text { Service provider should have skilled workers in a work in order that the work } \\
\text { is in line with the owner's expectation }\end{array}$ \\
\hline & $\begin{array}{l}\text { Inadequate supervisc } \\
\text { (contractor party) }\end{array}$ & $\begin{array}{l}\text { Service providers should have their own leader in a project which is in } \\
\text { accordance with each skill functioning as work result supervisor }\end{array}$ \\
\hline
\end{tabular}

Work Environment Factor is the variable which has coefficient value of $\beta$ as it is means that in this research, the most dominanct factor affecting Time Delay is Work Environment Factor. It means that Time Delay is extremely affected by Work Environment Factor. The coefficient value of $\beta$ which is positive indicating that if the project implemented is not in line with the determined time and the delay does not happen. Afterwards, to know which factor that affects Time Delay mostly in Work Environment Factor, it can be seen from high communality value in Table 11 as follows:

Table 11 - Communality Value in Work Environment Factor

\begin{tabular}{|c|c|c|}
\hline $\begin{array}{c}\text { Manifest } \\
\text { Variables }\end{array}$ & Description & $\begin{array}{c}\text { Communality } \\
\text { Value }\end{array}$ \\
\hline X7.1 & Rain frequenly occurs when implementing the project so that it obstructs the work & 0,845 \\
\hline X7.2 & The change of land, layout, or site which has been determined & 0,845 \\
\hline
\end{tabular}

Source: Analysis Result of SPSS.23. 
From table 11, it is known that the indicator of Work Environment Factor which is mostly dominant affecting Time Delay is frequent rain when implementing the work so that it obstructs the work of 0,845 and the change of land, layout, or site which has been determined of 0,845 . Then, the strategy used to prevent it can be seen in Table 12 below:

Table 12 - Preventive Strategy of Time Delay Causing Factor in Work Environment Factor

\begin{tabular}{|c|l|l|}
\hline Factor & \multicolumn{1}{|c|}{ Problems } & \multicolumn{1}{c|}{ Strategies } \\
\hline \multirow{3}{*}{$\begin{array}{c}\text { Work } \\
\text { Environment }\end{array}$} & $\begin{array}{l}\text { Rain frequenly occurs } \\
\text { when implementing the } \\
\text { project so that it obstructs } \\
\text { the work }\end{array}$ & $\begin{array}{l}\text { Anticipating the environment condition earlier related to temperature and } \\
\text { weather, since the beginning of field changes, adding the number of } \\
\text { workers and working hours (extra hour) at the evening to change the lost } \\
\text { working days due to weather change. }\end{array}$ \\
\cline { 2 - 3 } & $\begin{array}{l}\text { The change of land, } \\
\text { layout, or site which has } \\
\text { been determined }\end{array}$ & $\begin{array}{l}\text { Before the work starts, socialization to community and local government } \\
\text { should be done to determine land, layout or site which will be used }\end{array}$ \\
\hline
\end{tabular}

Source: Processed by the researcher from some references.

\section{CONCLUSION}

From the research result and discussion which have been explain in the previous chapters, it can be concluded that:

Based on $\mathrm{F}$ test, it is obtained that simultaneously factors of Finance $(\mathrm{XI})$, Equipment (X2), Workers (X3), Material (X4), Implementation Method (X5) Design Change (X6) and Work Environment $(X 7)$ do not affect Time Delay colectively with value of $F_{\text {count }}=1,910$ < $F_{\text {table }}=2,400$. However, based on t test, partially the factors affecting Time Delay significantly in the project of Kaliorang District Office Development in East Kutai Regency are Workers factor (X3) and Work Environment factor (X7).

Based on multiple linear regression analysis, the most dominant factor affecting time delay in the project of Kaliorang District Office Development in East Kutai Regency is Workers factor with coefficient value of $\beta$ of $-0,787$.

The strategies used to prevent Time Delay in workers factor (X3) and work environment factor (X7) are:

- The contractor should add workers who have skills in line with the needs and the experts who have qualifications respectively;

- Anticipating environment condition of a site and socialization to community and local government to determine land, layout or site that will be used.

\section{SUGGESTIONS}

The contractor must use skilled workers, having high productivity, and having a responsibility in accomplishing works and experienced proven by skill certificate. If the skilled workers are limited, then it is suggested to recruit skilled workers from other places;

The contractor must be able to use implementation time effectively in accomplishing the project in order to avoid extra working time which can increase the cost;

This present research is done to know the factors affecting contract in time delay in the project of Kaliorang District Office Development in East Kutai Regency and the factors are worker and work environment. Hence, it is expected that the next researchers can analyze other factors, which are assumed, affect the delay in order to make this research more complete.

\section{REFERENCES}

1. Burns, R. B., \& Bursn, R. B. (2000). Introduction to research methods.

2. Johnson, T., Tarshis, A., \& Goldberg, G. (1982). U.S. Patent No. 4,355,372. Washington, DC: U.S. Patent and Trademark Office. 
3. Kawulich, B. B. (2005). Participant observation as a data collection method. In Forum Qualitative Sozialforschung/Forum: Qualitative Social Research

4. Neter, J., Kutner, M. H., Nachtsheim, C. J., \& Wasserman, W. (1996). Applied linear statistical models (Vol. 4, p. 318). Chicago: Irwin.

5. Onwuegbuzie, A. J., Daniel, L., \& Leech, N. L. (2007). Pearson product-moment correlation coefficient. Encyclopedia of measurement and statistics, 2(1), 751-756.

6. Palinkas, L. A., Horwitz, S. M., Green, C. A., Wisdom, J. P., Duan, N., \& Hoagwood, K. (2015). Purposeful sampling for qualitative data collection and analysis in mixed method implementation research. Administration and Policy in Mental Health and Mental Health Services Research, 42(5), 533-544.

7. Singarimbun, M. \& Effendi, S. 2006. Metode Penelitian Survai. Jakarta: LP3ES.

8. Sugiyono. (2010). Metode Penelitian Kuantitatif, Kualitatif, dan R\&D. Bandung: CV Alfabeta.

9. Umar, H. (2007). Metodologi Penelitian Bisnis. Jakarta: Gramedia Pustaka Utama. 